\title{
Obesity and COVID-19 Are We Looking for Simple or Sophisticated Causes?
}

ISSN: 2578-0263

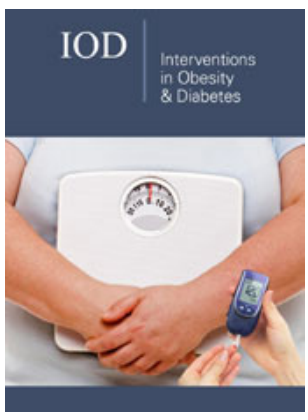

*Corresponding author: Karel Kubát, Department of Internal Medicine, Litomerice Hospital, Litomerice, Czech Republic

Submission: 海June 05, 2020

Published: 侮June 15, 2020

Volume 4 - Issue 2

How to cite this article: Karel Kubát. Obesity and COVID-19 Are We Looking for Simple or Sophisticated Causes? Interventions Obes Diabetes 4(2). IOD.000584. 2020. DOI: 10.31031/IOD.2020.04.000584

Copyright@ Karel Kubát. This article is distributed under the terms of the Creative Commons Attribution 4.0 International License, which permits unrestricted use and redistribution provided that the original author and source are credited.

\section{Karel Kubát*}

Department of Internal Medicine, Litomerice Hospital, Litomerice, Czech Republic

\section{Opinion}

High mortality from COVID-19 is in the group of patients suffering from malnutrition. People with severe diseases such as tumors, patients with heart failure, kidney failure, liver and other organ damage are at risk. COVID-19 was a particular problem for older people, and a resistance to social distancing and sheltering [1]. However, people with obesity and people with obesity and diabetes mellitus are also at risk. In the May issue of the prestigious Lancet magazine, the authors Kass DA, et al. [2] bring irrefutable data obtained by monitoring a large number of patients [2]. It has been shown that the unfavorable course of the disease surprisingly affected "good-looking" young people, young obese patients. How are the possible causes? Obesity can restrict ventilation by impeding diaphragm excursion [2], impairs immune responses to viral infection [3], is pro-inflammatory, and induces diabetes and oxidant stress to adversely affect cardiovascular function [4]. Data were obtained using univariate and multivariate linear regression models. The pharmacotherapy can solve problem of oxidative stress or pro-inflammatory factors. There will certainly be effective medicines in the future. Today, they are still tested for efficacy, safety and other clinical trials. We are not talking now about drugs that act directly on the virus (so-called antivirals). Many of them have already shown an excellent effect [5]. But back to obesity. It has also been found to be dangerous in view of the current viral infection. Is it possible to improve the condition without the help of drugs?

\section{Are we looking for simple or sophisticated causes?}

We believe that the association may be a higher density of ACE2 ${ }_{1,2,3, \ldots 9}$ receptors in obese due to genetic causes, differences in phosphorylation of basic amino acid residues in proteins, Ser/Thr/Tyr protein phosphorylation, differences in RNA-dependent RNA polymerase, genetic abnormalities in RNA transcription, but also acquired abnormalities in mRNA reverse transcriptase.... protein kinase B in insulin-induced glycogen synthase kinase 3 inactivation... coactivator CREB-binding protein abnormalities. The effect of HGPRT, MATE2, LKB1 ... in connection with variations in the transport of some amino acids intracellularly is considered. The influence of advanced glycation end products, the interaction at the level of basic cytochromes and, and... venous thromboembolism...and.. or?

\section{Is there a simple explanation?}

Could we consider the influence of the use of elevators (cars) by obese people? This factor could probably contribute to a higher aggregation of obese people in small spaces and thus to a higher infectious dose to which they are exposed. Obesity restricts ventilation. The lungs of people who have a "big belly" are significantly compressed while sitting and lying down. And we know that a person who suffers from a serious viral disease usually goes to bed. A large volume from the abdomen is also transferred to the chest, thus restricting breathing. CT scans of the lungs of patients with COVID-19 and obesity often provide a surprising picture of how much lung compression has occurred (personal statement-MUDr. Zbořil J). There is 
some other problem: Abdominal fat pushes on the stomach and "squeezes" the acidic stomach contents into the esophagus. Acidic gastric contents are often inhaled into the lungs. All the more so, the patient's lungs are damaged. And it is true that a large proportion of patients with COVID-19 died of severe pneumonia. Patients with reflux disease (GERD) and obesity are likely to suffer from lung damage more often. Damage to the lung parenchyma with hydrochloric acid $(\mathrm{HCl})$ is severe. But even if the production of acid by drugs is suppressed, the influx of stomach contents into the lungs is very risky: it contains a large amount of infectious particles (bacteria, viruses and others). Where drugs are administered to reduce the production of hydrochloric acid in the stomach, there is an increase in unnoticed "leakage into the lungs".

What could be "done" with the stomach? Operate the stomach? Have a "valve" made? Sure! Taking medication to improve stomach mobility? Sure! Sit in the waiting room with (rooms full of people) the appropriate specialists - and catch some infectious diseases there, such as Covid19? Sure? How can we improve our chances of overcoming the infection (and not rely on medication)? If we have "extra pounds", our prognosis will be better if we manage to lose weight. Or even better-if we manage to convert excess risky fat into the necessary muscle with the help of physical activity and adequate food. So break down fat and build muscle. Get in good shape. It's not just about reducing the number of kilograms on the scale display. We believe that people can improve their condition by their own efforts. It is better to be active and not to rely passively on drugs or other "crutches" passively. The author of this article also suffers from a certain degree of obesity. We believe that it is important to actively work on adjusting our lifestyle. It's good that we can enjoy moving! More than "good sweet" food. The current obesity pandemic is very dangerous. It is possible that an infectious disease (COVID-19) will make us eventually change our lifestyle.

\section{References}

1. Ludwig DS, Malley R (2020) Americans are already too diseased to go back to work right now.

2. Kass DA, Duggal P, Cingolani O (2020) Obesity could shift severe COVID-19 disease to younger ages. The Lancet 395(10236): 1544-1545.

3. Honce R, Schultz Cherry S (2019) Impact of obesity on influenza A virus pathogenesis, immune response, and evolution. Front Immunol 10: 1071.

4. GBD 2015 Obesity Collaborators, Afshin A, Forouzanfar MH, Reitsma MB, Sur P, et al. (2017) Health effects of overweight and obesity in 195 countries over 25 years. N Engl J Med 377(1): 13-27.

5. Sheahan TP, Amy C Sims, Sarah R Leist, Alexandra Schäfer, John Won, et al. (2020) Comparative therapeutic efficacy of remdesivir and combination lopinavir, ritonavir, and interferon beta against MERS-CoV. Nat Commun 11(1): 222. 